\title{
Incidences of nosocomial infection in Uruguayan adult intensive care unit 2010
}

\author{
SE Guerra, H Albornoz , R Rosa, M Godino, T Camou, A Galiana, S Martinez, G Rios, G Rehermann, H Bagnulo \\ From International Conference on Prevention \& Infection Control (ICPIC 2011) \\ Geneva, Switzerland. 29 June - 2 July 2011
}

\section{Introduction / objectives}

ICU patients (ptes) account for a large proportion of $\mathrm{HI}$. Its epidemiology allow us to identify key issues and prioritize interventions. We determined the incidence of $\mathrm{HI}$ in ICU in Uruguay and described specific locations, dispositive-associated rates and microorganisms.

\section{Methods}

A national surveillance system for $\mathrm{HI}$ was implemented in 2006; prospective surveillance was performed using NNISS criteria. It is mandatory, to record online and send their data to the Ministry of Health. Data are audited and results published annually.

\section{Results}

We present 2010 results of medical-surgical ICUs. 53 hospitals reported. 13611 ptes were surveyed (99541 ptes-days). $2340 \mathrm{HI}$ episodes were reported (density of incidence rate (ID) 23.5/1000 ptes-days and cumulative incidence $17.2 \%)$. Ventilator-associated pneumonia (VAP) (34\%), bronchitis (B) (28\%), catheter-associated urinary tract infection (CAUTI) (21\%) and central-line associated bacteremia (CLAB) (8\%) were the main infectious sites. VAP ID was 14.2/1000 ventilator-days (dispositive utilization (DU) 0.5 , secondary bacteremia (SB) $5.3 \%$ and contributor mortality (CM) 19.7\%), CLAB ID was 1.9/1000 catheter-days (DU 0.7, (CM) 17.7\%) and CAUTI ID was 5.8/1000 catheter-days (DU 0.8, (SB) 3.7\%, (CM) 5.1\%). Microorganisms were S. aureus (19, 17 , and $11.4 \%$ in VAP, B and CLAB), A. baumanii (VAP $22 \%$, B $18 \%)$, Ps. aeruginosa $(16,19,6.4$ and $10 \%$ in VAP, B, CLAB and CAUTI) and $K$. pneumoniae $(12,13$, 14.9 and $14 \%$ in VAP, B, CLAB and CAUTI).

$\overline{\text { Infection Control Committee, Ministry of Public Health, Montevideo, Uruguay }}$

\section{Conclusion}

Respiratory tract infections are the main problem. ICUs predominance of Gram Negative Bacilli in these infections may suggest the importance of exogenous sources. VAP and CAUTI rates are also high, diminish its incidence is priority for the national program.

\section{Disclosure of interest}

None declared.

Published: 29 June 2011

doi:10.1186/1753-6561-5-S6-P77

Cite this article as: Guerra et al:: Incidences of nosocomial infection in

Uruguayan adult intensive care unit 2010. BMC Proceedings 2011 5(Suppl 6):P77.
Submit your next manuscript to BioMed Central and take full advantage of:

- Convenient online submission

- Thorough peer review

- No space constraints or color figure charges

- Immediate publication on acceptance

- Inclusion in PubMed, CAS, Scopus and Google Scholar

- Research which is freely available for redistribution
() Bïmed Central

\section{Biomed Central}

